\title{
KEBIJAKAN SEKAYA MARITIM DALAM RANGKA PENINGKATAN KESEJAHTERAAN NELAYAN DI LAMPUNG TIMUR : ANALISIS TANTANGAN DAN PELUANG
}

Oleh:

\author{
Rachma Indriyani, Ayub Torry Satriyo, Diah Apriani Atika Sari
}

\begin{abstract}
Fishing has been a traditional occupation for millennia, supporting a plethora of communities, both along the sea coast and inland. However, traditional fishermen are under pressure from large scale unregulated industrialization, export-oriented, mechanized fishing and aquaculture. Therefore, it's community faced with deprivations of many kinds. The Ministry of Marine Affairs and Fisheries has been launching Sekaya Maritim program since early 2015, as an effort to improve the welfare of traditional fishermen. Considering that every region has different culture and problems to each other, then it should be a policy which appropriated to the real needs of local fishing communities. Nevertheless, one fits for all could not always fix all. Through descriptive approach and case study analysis, this paper reviews the Sekaya Maritim program applied in East Lampung, as well as map out the challenges and opportunities that should be a reflective matter for the government, so that the program could be optimally implemented and precisely targeted.
\end{abstract}

Keywords : Sekaya Maritim program, traditional fishermen, challenge, opportunity

\section{PENDAHULUAN}

Sebagai negara kepulauan terbesar dan seringkali digadang sebagai negara maritim berkat luasnya wilayah perairan, sudah selayaknya sektor kelautan dan perikanan menjadi urat nadi bagi perekonomian Indonesia. Tidak stagnan pada pemenuhan kebutuhan nasional semata, lebih daripada itu sumber daya kelautan semestinya turut menyejahterakan pelakunya, yakni para nelayan. Pada praktiknya, masyarakat nelayan merupakan kelompok yang dihadapkan pada kompleksitas permasalahan ekonomi. Kemiskinan telah melekat erat pada kelompok-kelompok ini, terutama bagi nelayan kecil. ${ }^{1}$ Berbeda dengan nelayan modern yang acapkali mampu merespon perubahan dan lebih kenyal dalam menyiasati tekanan perubahan dan kondisi over fishing, nelayan kecil yang umumnya bersifat tradisional seringkali mengalami proses marginalisasi dan menjadi korban dari program pembangunan dan modernisasi perikanan yang sifatnya ahistoris. Akibat keterbatasan teknologi yang dimiliki, ruang gerak nelayan tradisional umumnya sangat terbatas, yakni mereka

\footnotetext{
Djoko Wahju Winarno, Kebijakan Pemerintah Dalam Meningkatkan Kesejahteraan Nelayan (Studi Kebijakan Pemerintah pada Nelayan Pantai Timur Pulau Jawa), Disertasi, Yogyakarta : Fakultas Hukum Universitas Gadjah Mada, 2011, hlm 6
} 
hanya mampu beroperasi di perairan pantai (inshore). ${ }^{2}$

Semua fakta geografis Indonesia sebagai negara kepulauan dan negara pantai, turut menempatkan Indonesia sebagai negara dengan populasi nelayan yang patut diperhitungkan. Dilihat dari sumber data statistik Perikanan Tangkap di Indonesia, Jumlah Nelayan di Indonesia 2.748.908 orang, sedangkan untuk Individu Rumah Tangga Sasaran (RTS) Nelayan Miskin menurut data PPLS 2011 berjumlah 1.077.272 orang (261.609 RTS). Untuk mengurangi jumlah RTS tersebut beberapa kementerian yang tergabung dalam program PKN (Peningkatan Kesejahteraan Nelayan) telah mengupayakan penanggulangan kemiskinan tersebut dengan tujuan meningkatkan akses ketersediaan pelayanan dasar dan meningkatkan kualitas hidup masyarakat miskin.

Tahun 2015-2019 telah dicanangkan program PKN dengan tema Sekaya Maritim yaitu, Seribu Kampung Nelayan yang Mandiri Tangguh, Indah, dan Maju. Diharapkan dengan transformasi program PKN ini akan memberikan dampak positif bagi kehidupan nelayan dan lingkungan sekitarnya, meningkatkan pendapatan nelayan, serta memajukan daerah sasaran dengan ketersediaan tenaga terampil, penyerapan tenaga kerja, dan perkembangan sarana dan prasarana.

Kabupaten Lampung Timur merupakan satu-satunya Kabupaten di Provinsi Lampung yang menerima program Seribu

\footnotetext{
${ }^{2}$ Bagong Suyanto, "Mekanisme Survival, Identifikasi Kebutuhan dan Pemberdayaan Nelayan Miskin Dalam Masa Kritis Akibat Kenaikan Harga BBM", Jurnal Departemen Sosiologi FISIP Volume 24 Nomor 1 Universitas Airlangga: Surabaya, 2011, hlm. 75
}

Kampung Nelayan Mandiri Tangguh Indah dan Maju (Sekaya Maritim) dari Kementrian Kelautan dan Perikanan terhitung sejak tahun 2015 ini. Sasaran program Sekaya Maritim adalah peningkatan kesejahteran kehidupan nelayan kecil. Program itu mencakup sejumlah kegiatan, seperti pembangunan infrastruktur jalan, penyediaan sarana kesehatan, menerbitkan sertifikat tanah atas nama nelayan, memberikan bantuan alat tangkap ikan, dan melakukan perbaikan perumahan.

Berbagai kebijakan pemerintah dalam bidang perikanan dan kelautan semestinya dimaksudkan untuk melindungi kepentingan nelayan kecil, namun diperlukan pula pendekatan langsung kepada masyarakat agar implementasi peraturan perundangundangan dapat tepat sasaran. Sebagai komunitas yang rentan terhadap dampak degradasi lingkungan, nelayan tradisional perlu mendapatkan prioritas advokasi agar mereka tetap dapat menjalankan hak-haknya dengan sebagaimana mestinya. Dalam kaitannya dengan kebijakan Sekaya Maritim, perlu dikaji bagaimana tantangan dan peluang penerapan kebijakan tersebut dikaitkan dengan kondisi dan kebutuhan masyarakat nelayan pada umunya, dan nelayan di Kabupaten Lampung Timur, Provinsi Lampung pada khususnya.

\section{PEMBAHASAN}

\section{Landasan Hukum dan Framework}

Tidak dipungkiri bahwa kemajuan peradaban bangsa Indonesia dibangun dari kehidupan masyarakat yang sangat tergantung dengan sumberdaya pesisir dan lautan. Namun demikian dari era kemerdekaan sampai dengan saat ini hampir belum pernah ada kebijakan mengelola 
sumberdaya kelautan secara terpadu dibawah satu koordinasi lembaga negara. Dalam upaya pengembangan kegiatan ekonomi lokal, David Morris, dalam tulisannya yang berjudul "Communities; Building Authority Responsibility and Capacity", menekankan perlunya tiga landasan utama yang mendukung yakni : pertama, adanya kewenangan (authority), kedua, pertanggungjawaban (responsibility), dan ketiga, kapasitas produksi masyarakat (productivecapacity) yang menjamin keberdayaan masyarakat dalam menentukan masa depan kebijakan ekonomi. Terkait dengan tujuan pengembangan ekonomi lokal, Satish Kumar dalam tulisannya "Gandhi's Swadeshi Economic of Performance" menekankan bahwa arah dan tujuannya agar mampu menciptakan peningkatan semangat masyarakat (community spirit), hubungan masyarakat (community relationship) dan kesejahteraan masyarakat (well-being). ${ }^{3}$

Sekaya Maritim merupakan salah satu implementasi dari Instruksi Presiden (Inpres) Nomor 15 Tahun 2011 tentang Perlindungan Nelayan, dan Revitalisasi Program Peningkatan Kehidupan Nelayan (PKN) yang ditetapkan dalam Keputusan Presiden (Keppres) Nomor 10 Tahun 2011 tentang Tim Koordinasi Peningkatan dan Perluasan Program Pro-rakyat yang melibatkan Kementerian dan Lembaga yang terkait dengan nelayan yang sesuai dengan tugas dan fungsinya masingmasing. Program ini akan dilakukan secara bertahap pada tahun 2015, dengan menyasar hingga 1.000 desa/kelurahan di 330

\footnotetext{
${ }^{3}$ Tridoyo Kusumastanto, Pemberdayaan Sumber Daya Kelautan, Perikanan, dan Perhubungan Laut Dalam Abad XXI, Bogor: Institut Pertanian Bogor, hlm. 15
}

pelabuhan perikanan dan sentra perikanan seluruh Indonesia. Pada tahun 2015, program Sekaya Maritim ditargetkan akan difokuskan pada 31 lokasi sentra nelayan terpadu. Dilanjutkan dengan 200 kampung nelayan ditahun 2016, 300 kampung nelayan di tahun 2017. Program ini direncanakan hingga tahun 2019 dengan target 1.000 Kampung Nelayan.

Dalam rangka mencapai tujuan untuk meningkatkan kesejahteraan nelayan melalui berbagai program pro rakyat yang bersinergi dengan kementerian/lembaga serta perbankan sebagaimana yang diamanatkan di dalam Inpres tersebut, berikut adalah tugas, fungsi, dan kewenangan bagi Menteri Kelautan dan Perikanan :
a. mengoptimalkan pengelolaan sumber daya ikan;
b. menjamin ketersediaan bahan baku industri pengolahan ikan;
c. meningkatkan ketersediaan dan konsumsi sumber protein ikan;
d. mendorong perluasan kesempatan kerja di bidang perikanan;
e. mengutamakan upaya preventif dalam melakukan pengawasan sumber daya perikanan;

f. menindak tegas setiap pelaku penangkapan ikan secara melawan hukum, tidak dilaporkan, dan tidak diatur (Illegal, Unreported, Unregulated Fishing) dan penangkapan ikan yang merusak (destructive fishing) di Wilayah Pengelolaan Perikanan Negara Republik Indonesia;

g. memberikan perlindungan bagi nelayan dalam melakukan penangkapan ikan khususnya di wilayah perbatasan; 
h. menyiapkan kapal perikanan sampai dengan 60 GT dalam rangka restrukturisasi armada.

Terkait dengan upaya perlindungan nelayan yang tercantum dalam Inpres No. 15 Tahun 2011, saat ini belum ada peraturan perundang-undangan induk yang mengatur secara rigid dalam mengakomodir aspirasi dan eksistensi kelompok nelayan, namun sudah diinisiasi naskah Rancangan Undang-Undang (RUU) Perlindungan Nelayan dan Pembudidaya Ikan yang ditargetkan selesai dalam Program Legislasi Nasional (Prolegnas) Dewan Perwakilan Rakyat tahun 2015. Dalam RUU tersebut disebutkan bahwa perlindungan serta pemberdayaan nelayan dan pembudidaya ikan bertujuan antara lain menyediakan prasarana dan sarana untuk mengembangkan usaha, meningkatkan kemampuan, kapasitas, serta kelembagaan nelayan dan pembudidaya ikan dalam menjalankan usaha yang produktif, maju, modern, dan berkelanjutan, di samping melindungi dari risiko bencana alam dan perubahan iklim.

Pada Rencana Pembangunan Jangka Menengah Nasional (RPJMN) Tahun 2015 2019 disebutkan dalam visi yakni terwujudnya Indonesia yang berdaulat, mandiri, dan berkepribadian berlandaskan gotong royong. Salah satu misinya yakni mewujudkan Indonesia menjadi negara maritim yang mandiri, maju, kuat, dan berbasiskan kepentingan nasional. ${ }^{4}$ Dalam konteks inilah formulasi kebijakan dan peraturan yang dibuat sudah selayaknya

\footnotetext{
4 Kementrian Kelautan dan Perikanan, "Mengembalikan Kejayaan Ekonomi Maritim Untuk Kesejahteraan Rakyat" disampaikan pada RAPIMNAS 2014, Jakarta.
}

mengedepankan sektor kelautan dalam pembangunan nasional, baik dari peraturan induk hingga regulasi teknisnya.

\section{Justifikasi Persoalan dan Tantangan}

1. Gambaran umum Lampung Timur Kabupaten Lampung Timur diresmikan pada tanggal 27 April 1999, dibentuk berdasarkan Undang-Undang No. 12 tahun 1999 Tentang Pembentukan Kabupaten Daerah Tingkat II Way Kanan, Kabupaten Daerah Tingkat II Lampung Timur, Dan Kotamadya Daerah Tingkat II Metro. Ibukotanya berkedudukan di Sukadana dan memiliki luas wilayah kurang lebih $5.325,03 \mathrm{KM}^{2}$ atau sekitar $15 \%$ dari total wilayah Provinsi Lampung (total wilayah Lampung seluas $35.376 \mathrm{KM}^{2}$ ). Berlokasi di Kecamatan Labuhan Maringgai, Kabupaten ini merupakan satu-satunya Kabupaten di Provinsi Lampung yang menerima program Seribu Kampung Nelayan Tangguh Indah Mandiri (Sekaya Maritim) dari Kementrian Kelautan dan Perikanan terhitung sejak tahun 2015 ini. Sasaran program Sekaya Maritim adalah peningkatan kesejahteran kehidupan nelayan kecil. Program itu mencakup sejumlah kegiatan, seperti pembangunan infrastruktur jalan, penyediaan sarana kesehatan, menerbitkan sertifikat tanah atas nama nelayan, memberikan bantuan alat tangkap ikan, dan melakukan perbaikan perumahan.

Kecamatan Labuhan Maringgai memiliki enam desa dengan tipologi pesisir yaitu desa yang berbatasan langsung dengan laut. Empat desa di Kabupaten Lampung Timur 
mendapatkan program Sekaya Maritim pada tahun 2015, yakni Desa Sri Minosari, Karang Anyar, Sukorahayu dan Desa Margasari, Kecamatan Labuhan Maringgai. Mayoritas penduduk kedua desa tersebut bermata pencaharian sebagai nelayan $(66,12 \%)$ untuk memenuhi kebutuhan hidup sehari-hari. Nelayan adalah sebuah profesi yang memiliki ketergantungan pada ekosistem. Fenomena perubahan iklim yang terjadi akkhir-akhir ini, memberikan kendala tersendiri terkait waktu melaut bagi nelayan dan banyaknya hasil tangkapan, yang mana pada akhirnya kelayakan hidup semakin sulit diraih.

2. Identifikasi Persoalan dan Faktor Kendala

Rusaknya hutan mangrove di lingkungan pantai Kecamatan Labuhan Maringgai dan semakin mundurnya garis pantai menuju pemukiman, menempatkan nelayan pada ancaman abrasi, Desa Muara Gading Mas adalah salah satu yang cukup pelik. Abrasi pantai juga menyebabkan hilangnya lahan bahkan ancaman tenggelam sebagian besar wilayah pesisir, sehingga tidak dapat lagi dimanfaatkan oleh penduduk setempat. Keadaan diperparah dengan maraknya aktifitas penambangan pasir di pinggir pantai yang mulai merambah hingga ke Kecamatan Labuhan Maringgai turut menyebabkan jebolnya tanggul dan menghilangnya ikan dan kerang. Masyarakat nelayan yang mayoritas tinggal di pesisir terancam kehilangan tempat tinggal dan mata pencaharian, tidak terkecuali para nelayan di kecamatan Labuhan
Maringgai yang sebagian besar adalah nelayan tradisional yang melakukan penangkapan ikan dalam skala kecil dan bertujuan untuk memenuhi kebutuhan hidup sehari-hari.

Di sisi lain, Pemerintah setempat pada tahun 2011 sempat memberikan kelonggaran terhadap penggunaan jaring trawl dengan modifikasi dan jarak operasi diprasyaratkan sejauh 2 mil dari bagan nelayan tradisional. Sebagai penegasan dari Undang-Undang No.31 Tahun 2004 tentang Perikanan Pasal 9 ayat (1) menyebutkan larangan kepemilikan dan penggunaan alat tangkap ikan yang mengganggu dan merusak keberlanjutan sumber daya ikan di wilayah Indonesia, termasuk jaring trawl atau pukat harimau, dan/atau kompressor; telah disahkan Peraturan Menteri Kelautan dan Perikanan Nomor 2/Permen-KP/2015 tentang Larangan Penggunaan Alat Penangkapan Ikan Pukat Hela (Trawls) dan Pukat Tarik (Seine Nets) di Wilayah Pengelolaan Perikanan Negara Republik Indonesia. Namun, Pemerintah saat ini masih memperbolehkan penggunaan alat tangkap cantrang hingga 1 September 2015.

Di Kecamatan Labuhan Maringgai, masih seringkali ditemukan praktik alat tangkap yang tidak ramah lingkungan oleh nelayan, penggunaan bom ikan ataupun trawl kerapkali digunakan para nelayan di daerah ini, untuk mendapatkan hasil tangkapan yang lebih banyak. Beberapa kali peristiwa meledaknya bom ikan di perairan Desa Margasari menjadi sorotan nasional karena mengakibatkan korban luka dan 
tewas serta kerugian materiil bagi penduduk setempat.

Penggunaan jaring trawl dimaksudkan untuk meraup ikan dengan jala tarik di belakang kapal hingga ke bibir pantai. Sebagai dampak, terumbu karang rusak dan bukan hanya menjala ikan besar yang siap konsumsi tetapi ikan-ikan kecil dan bibit ikan pun ikut terangkut. Kondisi tersebut memicu terjadinya eksploitasi berlebih atau dikenal dengan over fishing. Pada akhirnya, tak ada regenerasi ikan di sekitar Pesisir Pantai Timur, terutama di Pantai Labuhan Maringgai. Kerusakan ekosistem di dekat pantai memaksa nelayan yang dahulu melaut di pinggir pantai kini harus berlayar ke tengah laut. Di tengah laut, nelayan kecil tradisional tidak mudah menangkap ikan karena harus bersaing dengan kapal besar milik perusahaan perikanan.

Apabila penggunaan alat tangkap yang tidak ramah lingkungan terus diberlakukan, para nelayan kecil akan semakin sulit mendapatkan tangkapan ikan dengan cara-cara yang konvensional dan kelestarian sumber daya hayati di perairan Labuhan Maringgai pun dapat terancam eksistensinya. Rusaknya ekosistem dan biota laut akan turut berdampak pada keberlangsungan sumber daya perikanan. Kalau sudah demikian, nelayan tradisional turut terancam untuk mendapatkan akses ke sumber daya perikanan atau daerah tangkapannya sendiri.

Tantangan lain yang dihadapi oleh masyarakat nelayan setempat yakni rendahnya tingkat pendidikan masyarakat dan akses untuk mendapatkan informasi sangatlah minim, sehingga terbatasnya informasi dan pengetahuan menyebabkan masyarakat tidak memahami penyebab, dampak dan solusi dalam menghadapi perubahan iklim, serta berbagai peraturan perundang-undangan terbaru dalam kelautan dan perikanan belum sepenuhnya terserap dan disosialisasikan secara tepat sasaran.

\begin{tabular}{|c|l|c|c|}
\hline No & \multicolumn{1}{|c|}{ Tingkat Pendidikan } & Jiwa & $(\%)$ \\
\hline 1 & Tamat Sekolah Dasar & 1784 & 63,39 \\
\hline 2 & Tamat SMP & 686 & 24,37 \\
\hline 3 & Tamat SMA & 309 & 10,98 \\
\hline 4 & Tamat Akademi/ D1-D3 & 30 & 1,06 \\
\hline 5 & Tamat Perguruan Tinggi & 17 & 0,60 \\
\hline 6 & Tamat SLB C & 5 & 0,17 \\
\hline & Jumlah & 2814 & $100,00 \%$ \\
\hline
\end{tabular}

Tabel 1. Presentasi Tingkat Pendidikan di Desa Margasari Tahun 2012

Sumber : Monografi Desa Margasari Tahun 2012 
Persoalan keamanan di laut merupakan ancaman selanjutnya, yang dihadapi para nelayan Lampung Timur setiap kali akan pergi melaut. Banyak terjadi kasus pembegalan di laut yang mengambil paksa hasil tangkapan nelayan beserta sarana melaut yang ada. Hal ini menjadi dilematis untuk para nelayan kecil yang menggantungkan kelangsungan hidupnya pada hasil melaut terlebih dengan pertaruhan harga bahan bakar yang harus dapat ditutup dengan hasil dari melaut tersebut.

Di dalam Undang-Undang Nomor 31 Tahun 2004 jo Undang-Undang Nomor 45 Tahun 2009 tentang Perikanan, nelayan kecil didefinisikan sebagai mereka yang menangkap ikan di laut dan menggunakan perahu di bawah 5 GT. Di lapangan, justru nelayan berkapasitas maksimal 5 GT inilah yang kesulitan mengakses BBM bersubsidi. Tidak terhubungnya fakta di perkampungan nelayan dengan penganggaran di Kementerian Kelautan dan Perikanan menjadi penyebab utama terkendalanya keseriusan pemerintah dalam menyejahterakan masyarakat nelayan. Sejumlah fakta tidak terhubungnya program pemerintah dengan upaya penyejahteraan nelayan di desa pesisir/perkampungan nelayan, di antaranya nelayan masih dihadapkan pada perkara terputusnya tata kelola hulu ke hilir; tiadanya jaminan perlindungan jiwa dan sosial (termasuk pendidikan dan kesehatan) bagi nelayan dan keluarganya; semakin sulitnya akses melaut akibat praktek pembangunan yang tidak ramah nelayan; serta ancaman bencana yang terjadi di wilayah pesisir dan pulau-pulau kecil. Lebih parah lagi, akses BBM bersubsidi masih menjadi perkara laten bagi masyarakat nelayan. ${ }^{5}$

Aktifitas melaut para nelayan ini juga berpotensi terkendala pada birokrasi administrasi perizinan kapal nelayan yang diamanatkan oleh UndangUndang No. 23 Tahun 2014 Tentang Pemerintah Daerah. Pasalnya, undangundang tersebut mengamanatkan urusan kelautan, pesisir dan pulau-pulau kecil, 70 persen diambil alih oleh pemerintah pusat dan 30 persen diambil alih oleh pemerintah daerah provinsi dan tanpa melibatkan pemerintah kabupaten atau kota. Pelaksanaan pengurusan izin yang selama ini didelegasikan hingga ketingkat kecamatan, menjadi terpusat di provinsi. Selama regulasi teknis dari undang-undang tersebut belum diatur, tidak menutup kemungkinan pendekatan layanan publik ke masyarakat hanya sebatas wacana.

\section{Implementasi Program Sekaya Maritim}

Dinas Kelautan dan Perikanan Lampung Timur menjadi leading sector di dalam mengidentifikasi persoalan-persoalan kemiskinan kelompok nelayan dan masyarakat wilayah pesisir, serta mengembangkan program prioritas pengentasan kemiskinan yang sesuai dengan persoalan dan karakteristik kemiskinan tersebut. Berbagai ahli menyatakan bahwa kebijakan pro-poor memiliki karakteristik penting, antara lain: (1) kebijakan atau program yang spesifik menargetkan

${ }^{5}$ Majalah Samudra Edisi 131, Tahun XII, Maret 2014 terkutip dalam "Menggenapkan Janji Kepada Nelayan" diakses dari kiara.or.id pada 27 September 2015. 
penyebab-penyebab kemiskinan atau penerima manfaat utamanya adalah kelompok miskin; (2) kebijakan atau program yang meningkatkan kondisi kehidupan kelompok miskin melalui penyediaan infrastruktur dasar dan infrastruktur pendukung perekonomian; (3) kebijakan atau program yang menargetkan penurunan biaya hidup bagi kelompok miskin. ${ }^{6}$

\section{Tinjauan Realisasi}

Program Sekaya Maritim adalah proyek percontohan untuk daerah pantai di Lampung dan sebagai kelanjutan dari hasil musyawarah 1.000 nelayan pada November 2014 yang membahas pengembangan kehidupan nelayan. Kecamatan Labuhan Maringgai masuk urutan delapan besar skala nasional dalam program Sekaya Maritim setelah Bangka Belitung. ${ }^{7}$

Berdasarkan data yang didapat, program Sekaya Maritim yang telah diterapkan meliputi bantuan pembangunan sarana dan infrastruktur. Di Desa Margasari, beberapa program yang diterima di antaranya yakni pembangunan drainase, jalan setapak, pembuatan bak sampah serta sarana MCK. Proses revitalisasi juga diterapkan pada tempat pelelangan ikan (TPI). Selama ini nelayan enggan menjual hasil tangkapannya di TPI. Mereka memilih membongkar hasil tangkapannya di

\footnotetext{
6 Korayem, Karina, "Pro-Poor Policies in Egypt: Identification and Assessment", International Journal of Political Economy, Vol. 32. No. 2. 2004.

7 Ali Johan, "KPD Dinas Kelautan dan Perikanan", dikutip dari http://sumatra.bisnis.com/ diakses pada 05 Oktober 2015.
}

sepanjang aliran Sungai Way Penet.. Untuk memfungsikan TPI tersebut, akan ada perbaikan dan pembangunan TPI, salah satunya pembuatan breakwater atau pemecah ombak agar pendalaman bibir pantai bisa dikerjakan. Bibir pantai di TPI Way Penet terlalu dangkal sehingga kapal nelayan tidak bisa mendarat untuk menjual hasil tangkapannya di tempat itu. Demi tercapainya realisasi program secara optimal, di desa tersebut telah dilakukan upaya pendataan nelayan melalui kartu nelayan dan sejauh ini mendapatkan respon positif dari masyarakat nelayan setempat.

Program yang segera direalisasikan di Desa Sukorahayu yakni ditargetkan ada pembangunan rumah nelayan sebanyak 100 unit beserta sertifikat tanah, serta bedah rumah kurang layak menjadi layak huni yakni sebanyak 60 unit.

Untuk meningkatkan perekonomian nelayan, juga diusulkan pengadaan alat tangkap berupa mini colt storage, jaring layang (jaring fly) sebanyak 1000 potong, kapal untuk nelayan desa sebanyak 20 unit ukuran 5 GT, serta sarana-sarana kesehatan antara lain berupa mobil ambulans.

Berdasarkan hasil kajian, sejauh ini realisasi program Sekaya Maritim terutama difokuskan pada sarana dan infrastruktur untuk menunjang kegiatan penangkapan ikan oleh masyarakat nelayan. Namun, sejatinya nelayan bukan hanya membutuhkan sarana kapal maupun alat tangkap, ketersediaan akses modal usaha sebagai biaya operasional di kala melaut dan tata niaga perikanan 
yang baik sehingga hasil tangkapan memiliki harga jual bersaing, adalah langkah kongkrit yang dibutuhkan untuk dapat meningkatkan kesejahteraan nelayan.

Penjelasan di atas, menunjukkan bahwa dalam upaya pelaksanaan program Sekaya Maritim, dibutuhkan kerjasama lintas sektor antar lembaga, bukan hanya Kementrian Kelautan dan Perikanan. Koordinasi adalah keniscayaan untuk peningkatan kesejahteraan nelayan. Kementrian Usaha Mikro, Kecil , dan Menengah (UMKM) misalnya, yang dapat megambil peran dalam pemberdayaan nelayan. Kebijakan pemberdayaan pun harus lebih luas daripada sekedar membuat daftar program bantuan finansial dan teknis yang berdiri sendiri tanpa ada kaitan antara satu dan lainnya. Isu pokok yang kerapkali terjadi yakni tidak adanya kesinambungan program karena implementasinya bersifat trial and error. ${ }^{8}$ Dalam hal ini, nelayan sebagai simbol dianggap mewakili kelompok lain yang menghadapi nasib atau persoalan serupa, khususnya kemiskinan dan rendahnya pendidikan. Oleh karenanya, keberhasilan nelayan dapat menjadi contoh untuk memberdayakan kelompok miskin lainnya meskipun tidak berkait dengan laut.

Sinergi multidimensi lainnya dalam mendukung upaya menaikkan kelas dan

8 Teuku Syarif, "Pendekatan dan Strategi Pembangunan Ekonomi yang Berorientasi Pada Perbaikan Iklim Usaha UMKM" 2007, terkutip dalam Herman Khaeron, Transformasi Politik Kelautan Indonesia Untuk Kesejahteraan Rakyat, Jakarta : Pustaka Cidesindo, 2012, hlm 167 skala hidup keluarga nelayan di pesisir, semestinya juga diterapkan pada pembangunan fasilitas infrastruktur jalan dengan Kementerian Pekerjaan Umum, membantu pendidikan anak-anak nelayan secara gratis melalui Kementerian Pendidikan Nasional. Ada pula di bidang kesehatan, dapat diterapkan melalui pemeriksaan kesehatan bayi dan ibu dengan Kementerian Kesehatan, juga pembangunan sarana air bersih, sanitasi melalui Kementerian Perumahan Rakyat. Dengan pemenuhan fasilitas yang lebih memadai diharapkan mampu memberikan kenyamanan masyarakat. Lingkungan yang nyaman dapat memberikan dampak posistif pula bagi hasil kerja dan kelangsungan usaha para nelayan. Sehingga, produktivitas kegiatan perikanan diharapkan akan semakin meningkat.

Program Sekaya Maritim yang diterapkan di desa-desa di Lampung Timur sudah seharusnya didukung dengan pendekatan sosialisasi dan dialog interaktif kepada masyarakat nelayan yang dijadikan target. Namun, masih minimnya akses informasi yang ada sehingga seringkali nelayan yang bersangkutan belum mengetahui kebijakan-kebijakan yang dikeluarkan oleh pemerintah. Selain itu, di beberapa desa struktur kelompok nelayan setempat belum terorganisir secara mumpuni, sehingga tidak bisa segera responsif apabila ada informasi yang diterima, hal ini dapat menjadi faktor penghalang bagi lancarnya koordinasi. 


\section{Memetakan Peluang}

Dalam konsep kekinian, nelayan merupakan salah satu subjek pembangunan pemerintah dalam ranah kelautan dan perikanan. Sebabnya, keadaan nelayan yang selama ini terpuruk, termanfaatkan tanpa diuntungkan, kelompok nelayan tradisional sesungguhnya adalah bagian dari komunitas masyarakat pesisir yang tergolong paling rentan, tidak berdaya, dan menjadi korban pertama yang paling menderita dari kebijakan modernisasi perikanan. Kehidupan sehari-hari keluarga nelayan ini bukan hanya diwarnai dengan kemiskinan dan berbagai keterbatasan, tetapi juga nyaris tidak ada peluang atau kesempatan untuk melakukan mobilitas vertikal. Tidak dimilikinya modal yang cukup dan asset produksi yang memadai, seringkali menyebabkan mereka terpaksa hidup pas-pasan, atau bahkan kekurangan ketika musim paceklik ikan tiba.

Berdasarkan analisa dari tinjauan realiasasi, diketahui bahwa semua program Sekaya Maritim di Kabupaten Lampung Timur belum terimplementasi secara paripurna. Selain itu, jika dipadankan dengan identifikasi berbagai persoalan yang dihadapi oleh masyarakat nelayan setempat, seperti ancaman degradasi lingkungan, perubahan iklim, sosial budaya, keamanan, hingga pendidikan, program yang tertuang di dalam Sekaya Maritim belum dapat mengakomodir semua kendala tersebut. Dari segi substansi, apapun bantuan yang diberikan kepada kelompok nelayan tradisional, hendaknya tidak berorientasi pada kepentingan jangka pendek yang sekedar penguliran dana atau efisiensi pengembalian dana, namun harus berorientasi pada pemupukan investasi yang bersifat jangka panjang dan strategis.

Dari segi eksekusi, efektifitas kebijakan harus diikuti dengan sosialisasi dan sekaligus solusi kepada seluruh masyarakat dan stakeholders di sektor tersebut. Terkait pengelolaan sumber daya pesisir dan laut, suatu kebijakan dan peraturan yang ada harus memperhatikan dimensi dan karakteristik sosial masyarakat yang dijadikan sasaran. Pengaturan pengelolaan sumberdaya hendaknya berbasis pada pengembangan ekonomi dan kesadaran hukum masyarakat lokal. Berbasis pada kebutuhan (need oriented of law) artinya peraturan yang ada didasarkan pada kebutuhan suatu kelompok masyarakat di kawasan pesisir. Berbasis pada prakarsa lokal (local initiatives of law) artinya peraturan yang ada lebih didasarkan pada prakarsa dan kesadaran hukum masyarakat lokal dikawasan pesisir. Adanya prakarsa masyarakat untuk menerapkan suatu peraturan hendaknya menjadi landasan dan rekomendasi bagi instansi yang berwewenang dalam mengeluarkan peraturan. ${ }^{9}$

Dalam rangka memperbaiki taraf hidup dan memberi peluang kepada nelayan tradisional agar dapat melakukan mobilitas vertikal, paling tidak ada dua jalan yang bisa ditempuh. Pertama, dengan jalan mendorong pergeseran nelayan tradisional menjadi

\footnotetext{
${ }^{9}$ Tridoyo Kusumastanto, op.cit, hlm. 17.
} 
nelayan modern. Kedua, dengan cara tetap membiarkan nelayan dalam status 'tradisional', tetapi memfasilitasi mereka agar lebih berdaya dan memiliki kemampuan penyangga ekonomi keluarga yang kenyal terhadap tekanan krisis. Cara mana yang akan dipilih tergantung pada faktor pendukung internal seperti potensi kondisi nelayan setempat maupun faktor pendukung eksternal, yakni sumber daya pemerintah. ${ }^{10}$

Berdasarkan kondisi sumber daya lokal di Kabupaten Lampung Timur, berikut adalah potensi yang dapat dimanfaatkan untuk memetakan kebutuhan masyarakat nelayan setempat:

${ }^{10}$ Bagong Suyanto, Anatomi Kemiskinan dan Strategi Penanganannya, Malang: Intrans Publishing, 2013, hlm 91. 


\begin{tabular}{|c|c|c|c|}
\hline No & Potensi & Tujuan dan Sasaran & Program \\
\hline 1 & $\begin{array}{l}\text { Potensi ikan kerapu yang cukup } \\
\text { besar, namun pasokan ikan kerapu } \\
\text { masih mengandalkan hasil } \\
\text { tangkapan dari alam, yang belum } \\
\text { mencukupi permintaan pasar. }{ }^{11} \\
\text { Meski banyak terdapat sentra } \\
\text { kerupuk ikan, namun pengolahan } \\
\text { hasil tangkapan masih dilakukan } \\
\text { secara tradisional sehingga belum } \\
\text { memahami bagaimana membuat } \\
\text { hasil laut menjadi bernilai } \\
\text { ekonomis. }\end{array}$ & $\begin{array}{l}\text { Peningkatan terhadap kualitas } \\
\text { keterampilan sumber daya } \\
\text { manusia }\end{array}$ & $\begin{array}{l}\text { a. Penyuluhan perikanan } \\
\text { dan lingkungan hidup } \\
\text { b. Pelatihan manajemen } \\
\text { usaha dan pemasaran } \\
\text { c. Bantuan modal usaha, } \\
\text { kredit lunak } \\
\text { d. Koordinasi hulu dan } \\
\text { hilir hingga akses pasar } \\
\text { ekspor } \\
\text { e. Pembentukan struktur } \\
\text { kepengurusan bagi } \\
\text { komunitas nelayan }\end{array}$ \\
\hline 2 & $\begin{array}{l}\text { Secara geografis langsung } \\
\text { berbatasan dengan laut, bahkan } \\
\text { berdekatan dengan laut lepas } \\
\text { yang belum dieksploitasi secara } \\
\text { optimal, dan beberapa desa sudah } \\
\text { memiliki pelabuhan perikanan } \\
\text { dan tempat pelelangan ikan, } \\
\text { namun banyak yang tidak } \\
\text { difungsikan. }\end{array}$ & $\begin{array}{l}\text { membuka akses yang luas bagi } \\
\text { pemanfaatan sumber daya } \\
\text { kelautan, namun tetap berpijak } \\
\text { pada rambu-rambu hukum }\end{array}$ & $\begin{array}{l}\text { a. Sosialisasi peraturan } \\
\text { perundang-undangan } \\
\text { b. Revitalisasi dermaga } \\
\text { perikanan dan TPI, } \\
\text { beserta sumber daya } \\
\text { manusianya ( petugas } \\
\text { Syahbandar) } \\
\text { c. Peningkatan patroli } \\
\text { dan pos siaga untuk } \\
\text { penegakan hukum dan } \\
\text { pencegahan } \\
\text { kriminalitas } \\
\text { d. Pembekalan advokasi } \\
\text { bagi kelompok nelayan }\end{array}$ \\
\hline 3 & $\begin{array}{l}\text { Terdapat beberapa } \\
\text { antara instansi dan masama } \\
\text { dalam upaya } \\
\text { mangrove. }\end{array}$ & $\begin{array}{l}\text { mendayagunakan potensi } \\
\text { ekonomi dan sumberdaya } \\
\text { pesisir dan lautan dengan turut } \\
\text { memperhatikan aspek-aspek } \\
\text { kelestarian dan keberlanjutan } \\
\text { lingkungan (sustainable and } \\
\text { environmentally friendly). }\end{array}$ & $\begin{array}{l}\text { a. Adaptasi dan Mitigasi } \\
\text { bencana } \\
\text { b. Pemberian insentif } \\
\text { bagi pegiat lingkungan } \\
\text { hidup } \\
\text { c. Diversikasi usaha non- } \\
\text { perikanan } \\
\text { d. Kerjasama Perguruan } \\
\text { Tinggi melalui Kuliah } \\
\text { Kerja Nyata bagi } \\
\text { mahasiswa }\end{array}$ \\
\hline
\end{tabular}

Tabel 2. Strategi pemberdayaan peluang

${ }^{11}$ Lihat www.lampungtimurkab.go.id, diakses pada 10 Oktober 2015. 
Dari tabel di atas dapat dirangkum mengenai rencana strategi pengembangan hukum tujuan dan sasaran yang diharapkan adalah (1) mampu menghidupkan kegiatan ekonomi produktif berbasis sumber daya lokal baik sumberdaya perikanan maupun sumberdaya manusia yakni keterampilan dan budaya artinya bahwa pemberdayaan nelayan harus dilakukan dalam rangka pengembangan pemanfaatan sumberdaya perikanan dan peningkatan kualitas ketrampilan dan budaya kelompok masyarakat nelayan, (2) mampu membuka akses yang luas bagi masyarakat terhadap pemanfaatan sumberdaya kelautan sehingga masyarakat bebas memanfaaatkan dan mengelola sumberdaya pesisir dan lautan untuk dipergunakan sebagai instrumen mencapai kemakmuran, namun tetap berpijak pada rambu-rambu hukum, (3) mampu mendayagunakan potensi ekonomi dan sumberdaya pesisir dan lautan secara optimal dengan memperhatikan aspek sustainable and environmentally friendly. ${ }^{12}$

\section{KESIMPULAN}

Untuk menjadikan kelautan sebagai leading sector dalam pembangunan, maka pendekatan kebijakan yang dilakukan harus mempertimbangkan keterkaitan antar sektor ekonomi dalam lingkup bidang kelautan. Dalam hal perencanaan pembangunan serta implementasinya dirasakan pentingnya peran koordinasi antar institusi pemerintah yang membidangi kelautan agar dapat mempercepat peningkatan peran sumberdaya kelautan dalam memperkokoh

\footnotetext{
12 Tridoyo Kusumastanto, op.cit.
}

perekonomian nasional dalam era yang sangat kompetitif. Penerapan program Sekaya Maritim yang sudah dalam tahap implementasi harus dibarengi dengan pengawasan yang ketat sehingga bisa tepat sasaran dan manfaatnya dirasakan para nelayan. Pada pelaksanaan program di Kabupaten Lampung Timur, pemberian bantuan selain untuk pemenuhan kebutuhan nelayan seperti bantuan rumah, alat tangkap, dan kapal nelayan, diperlukan juga bantuan yang bersifat investasi jangka panjang dan berkelanjutan, seperti pengembangan sarana dan prasarana pengolahan hasil melaut dan pemasaran di Lokasi peningkatan kesejahteraan nelayan (PKN), serta pengendalian dan pengawasan penerapan jaminan mutu dan keamanan hasil perikanan.

\section{DAFTAR PUSTAKA}

\section{Buku dan Karya Ilmiah}

Bagong Suyanto, Anatomi Kemiskinan dan Strategi Penanganannya, Malang : Intrans Publishing, 2013

Bagong Suyanto, Mekanisme Survival, Identifikasi Kebutuhan dan Pemberdayaan Nelayan Miskin Dalam Masa Kritis Akibat Kenaikan Harga BBM, Jurnal Departemen Sosiologi FISIP Volume 24 Nomor 1,Universitas Airlangga : Surabaya.. 2011

Djoko Wahju Winarno. Kebijakan Pemerintah Dalam Meningkatkan Kesejahteraan Nelayan (Studi Kebijakan Pemerintah pada Nelayan 
Pantai Timur Pulau Jawa).

Disertasi. Yogyakarta: Fakultas

Perikanan Negara Republik

Hukum Universitas Gadjah Mada.

2011

Herman Khaeron. Transformasi Politik

Kelautan Indonesia Untuk

Kesejahteraan Rakyat. Jakarta :

Pustaka Cidesindo. 2012.

Korayem, Karina, "Pro-Poor Policies in Egypt : Identification and

Assessment", International Journal of Political Economy Vol. 32. No. 2. 2004.

Tridoyo Kusumastanto, Pemberdayaan Sumber Daya Kelautan, Perikanan, dan Perhubungan Laut Dalam Abad XXI, Bogor : Institut Pertanian Bogor

\section{Peraturan Perundang-undangan}

Undang-Undang No. 23 Tahun 2014 Tentang Pemerintah Daerah.

Undang-Undang No.31 Tahun 2004 jo Undang-Undang Nomor 45 Tahun 2009 tentang

Perikanan

Instruksi Presiden (Inpres) Nomor 15 Tahun 2011 tentang Perlindungan Nelayan

Peraturan Menteri Kelautan dan Perikanan Nomor 2/Permen-KP/2015 tentang Larangan Penggunaan Alat Penangkapan Ikan Pukat Hela (Trawls) dan Pukat Tarik (Seine Nets) di Wilayah Pengelolaan 